\title{
Effect of Selected Factors on Non-performing Agricultural Loans in Commercial Banks in Kenya
}

\author{
Boiyon Geoffrey Kibet ${ }^{1}$, Richard Nyaoga ${ }^{2}$, Robert Kingwara ${ }^{2}$ \\ ${ }^{1}$ School of Business, Egerton University, Nakuru, Kenya \\ ${ }^{2}$ Department of Accounting, Finance \& Management Science, Egerton University, Nakuru, Kenya
}

Email address:

boiyon2003@yahoo.com (B. G. Kibet)

\section{To cite this article:}

Boiyon Geoffrey Kibet, Richard Nyaoga, Robert Kingwara. Effect of Selected Factors on Non-performing Agricultural Loans in Commercial Banks in Kenya. International Journal of Finance and Banking Research. Vol. 6, No. 5, 2020, pp. 90-95. doi: 10.11648/j.ijfbr.20200605.11

Received: July 25, 2020; Accepted: August 18, 2020; Published: September 19, 2020

\begin{abstract}
Commercial banks plays a crucial role in the Agricultural sector in advancing farmers affordable credit to improve their productivity, enhancing their food security, and expanding their income. Financing of the sector however continues to get the lowest levels of credit in Kenya compared to other sectors due to poor loan repayment. This study aimed to establish the effect of macro-economic factors of Gross Domestic Product (GDP), Real Effective Exchange Rate, and the Lending rate on Agricultural Non-performing Loans (NPL) and to assess the effect of Growth in Loan Portfolio on Agricultural NPL. Secondary data relating to Commercial Banks lending to the agricultural sector for a period of 7 years from 2011 to 2017 was collected from forty-two Commercial Banks in Kenya. Results showed that agricultural NPL had a strong positive correlation with real GDP $(0.836, \mathrm{p}<0.001)$, the Real Effective Exchange rate $(0.865, \mathrm{p}<0.001)$, and a weak inverse correlation with the average Bank Lending rate $(-0.48, \mathrm{p}<0.01)$. The study concluded that commercial banks should pay close attention to the two factors (Gross Domestic Product and Real Effective Exchange rate) when providing loans to the agricultural sector to reduce the level of impaired loans. The banks active in agricultural lending should, therefore, take the performance of the real economy into account when extending loans given the reality that loan delinquencies are likely to be higher during periods of economic boom as suggested by the study results. Equally Commercial banks should trade with high prudence to curb a possible impairment due to reckless lending and over-estimation of the borrower's ability to pay back. They should constantly review the complexity and diversity of the new loans to the agricultural sector periodically like quarterly, and do aging analysis to ensure that the growth in agricultural loans do not serve to window dress the portfolio at risk percentage while the actual amounts in default are increasing.
\end{abstract}

Keywords: Agricultural Loans, Credit, Non-performing Loans, Macro-economic Environment, GDP, Interest Rates

\section{Introduction}

The demand for agricultural loans in Kenya has been increasing the past three decades in response to the increasing opportunities to expand production and value addition of agricultural produce. According to the Central Bank of Kenya bank supervision report (2015), gross loans and advances increased from Kshs 1.94078 trillion in 2014 to Kshs 2.1653 trillion in 2015 which translated to a growth of 11.57 percent. Of all the loans, the banks gave Kshs 551.063 billion to households/personal loans, trade (Kshs 42.362 billion), agriculture (Kshs 87.456 billion) manufacturing (Kshs 266.389 billion) and real estate (Kshs 293.989 billion) during this period under review. Eight out of eleven sectors funded (including agriculture) registered an increase in Nonperforming loans (NPLs) [6].

Agricultural Farming in the country continues to get the lowest levels of credit between 4 and 6 percent from the year 2000 to 2015 compared to other sectors of the economy due to high risks associated with it such as drought, floods and the inability of small-scale farmers to provide collateral for their loans [5]. Treasury data shows that total loans advanced to the agriculture sector shrunk by Sh13.737 billion in the year 2017 from Kshs 93.712 in 2016 to Kshs 79.975 in 2017 indicating that loan repayments were more than new disbursements. Loans issued to farmers represent less than 3 percent of the Sh1.6 trillion loaned out to the private sector by banks despite it contributing a fifth of the country's GDP [6]. 
Agriculture has been a source of distress to some lending institutions like Faulu Kenya which wrote off a bulk of loans issued to farmers in North Rift Kenya in 2010 due to defaults and the government-owned Agricultural Finance Corporation. Most of the lend out funds continue to be either difficult to collect or uncollectible altogether [6]. Since agriculture is the mainstay of the Kenyan economy, agricultural lending defaults or delinquency, is a major concern to policymakers because of its unintended negative impacts on agricultural financing. Should the financiers in this sector experience liquidity problems or introduce stringent requirements, the economy will largely stagnate or at worst depress and the country's balance of payments will be unfavorable. Some of the other impacts associated with default include the inability to revolving funds to other borrowers; unwillingness of other financial intermediaries to serve the needs of small borrowers; and the creation of distrust $[17,9]$.

The costs of non-performing loans would also be felt by both the lenders and the borrowers. The lender has costs in delinquency situations, including lost interest, the opportunity cost of principal, legal fees, and related costs. Non-performing loans eat into management time, increase administration costs and lead to lost focus whereas attention would be focused on getting more volumes to achieve the stated business objectives; it is shifted to getting the loans repaid. [3].

The poor in the rural set up face a highly diverse range of financial needs and opportunities that need to be addressed effectively. Promoting an efficient, sustainable and widely accessible rural financing system remains a major development challenge in most sub-Saharan African countries $[18,2]$.

\section{Literature Review}

Several institutions provide credit to the agriculture sector in Kenya. These include Commercial Banks; non-bank financial institutions and multilateral organizations. Commercial banks in Kenya are licensed and regulated pursuant to the provisions of the Banking Act (Cap 488) and the regulations and prudential guidelines issued by the Central Bank of Kenya. The main Commercial Banks involved in agriculture lending and savings mobilization in Kenya are; Kenya Commercial Bank, Equity Bank, Transnational bank, Family bank, chase bank, Cooperative bank, Jamii Bora Bank, Diamond trust bank, CFC Stanbic bank and Sidian bank. Other institutions include development financial institutions (DFI) like AFC, rural SACCOs, FSA's, and MFI's. MFIs fill some of this financial gap with credit facilities to poor people, mainly based on the Grameen Bank group-based model [14].

The existing financial products and methodologies do not allow the agriculture sector to have extensive reach as the need for the services demands despite huge investment in the financial sector in Kenya. For most Banks, financing agriculture is a high-risk activity because of low profitability in the sector, high nominal inflation, problems with collateral because of uncertain property rights, ineffective land markets, and the lack of well-established relationships between farmers and new producers.

Low farm profitability is a key factor in agricultural and rural finance problems, restricting the demand for and supply of credit in transitional economies. The existence of high levels of non-performing loans (NPLs) in the banking industry in Kenya negatively affects the level of private investment, impair a bank's ability to settle its liabilities when they fall due and constrain the scope of bank credit to borrowers [18].

There has been a general perception among banks that credit exposure to the agricultural sector contributes to a bank's failure or its success [13]. Research has however proved that credit exposure to farmers does not necessarily contribute to failures in the banking industry because loans are negotiated in a competitive environment and thus banks have learned to employ credit risks model to hedge against defaults [16]. The findings of the study challenged the bank's view of agricultural lending and the subjectivity of their lending processes and to improve the accountability of lending officers instead of adopting a theoretically-driven approach without looking at the salient issues that would otherwise be hidden when making lending decisions [16].

However, any limitation, when added to irregular availability of loans, affects the performance of bank loans. The performance of banks is measured in terms of loan disbursements rather than in a number of small-farmer borrowers. Study on whether loan growth affects the riskiness of individual banks in 16 major countries using bank scope data from more than 16,000 individual banks during 1997-2007 found that loan growth leads to an increase in loan loss provisions during the subsequent three years, to a decrease in relative interest income, and lower capital ratios [8]. Research has shown that agriculture is a risky sector and this can be demonstrated by the factors associated with agricultural lending: - lower loan repayment, longer distance to serve farmers, poor infrastructure, and little knowledge about heterogeneous farm households [1].

There are concerns about the drivers of NPLs in Kenya and whether the macroeconomic environment should be held responsible for its increase. This study investigates the factors that influence the NPLs in the agricultural sector.

\section{Methodology}

\subsection{Data Sources}

This study used secondary data collected with the use of data collection schedules and questionnaires. The secondary data on gross loans and nonperforming loans for the banking industry was collected from the Central Bank of Kenya's annual bank supervision reports. Data on macroeconomic indicators were collected from economic survey reports of the Kenya National Bureau of Statistics [11]. This enabled the researcher to get quantified data that was helpful to draw conclusions. Data was collected relates to a period of seven years from 2011-2017. This period has been chosen to get the most up to date and expansive data view to help the 
researcher draw a reasonable conclusion.

\subsection{Data Analysis}

The collected data were processed by editing, coding, classifying, and tabulating to ease processing and analysis. The trend in the loan portfolio and NPL is calculated by plotting graphs of the variables over time. Regression analysis was used to establish the effect of the selected factors on non-performing agricultural loans. Regression analysis assessed the strength of the relationship among a set of predictor variables on the criterion variable. In this study, the independent variables included gross domestic product, real effective exchange rate, lending rate, and growth in the loan portfolio and the dependent variable is nonperforming agricultural loans. F-test was used to test for significant differences between the factor means. The following regression equation was used:

$$
Y=a+\beta_{1} x_{1}+\beta_{2} \chi_{2}+\beta_{3} \chi_{3}+\beta_{4} \chi_{4}+\varepsilon
$$

Where:

$\mathrm{Y}=$ Non performing agricultural loans (\%)

Where:

$\mathrm{a}=$ Constant

$\mathrm{X}_{1}=$ Gross Domestic Product (GDP)

$\mathrm{X}_{2}=$ Real Effective Exchange Rate (REER)

$\mathrm{X}_{3}=$ Lending rate

$\mathrm{X}_{4}=$ growth in the loan portfolio

$\beta_{1}, \beta_{2}, \beta_{3}, \beta_{4}=$ are the coefficient of the independent variables i.e. $\mathrm{X}_{1}, \mathrm{X}_{2}, \mathrm{X}_{3}, \mathrm{X}_{4}$

$\mathcal{E}=$ random error term.

Non-performing Loans (NPL) will be measured as

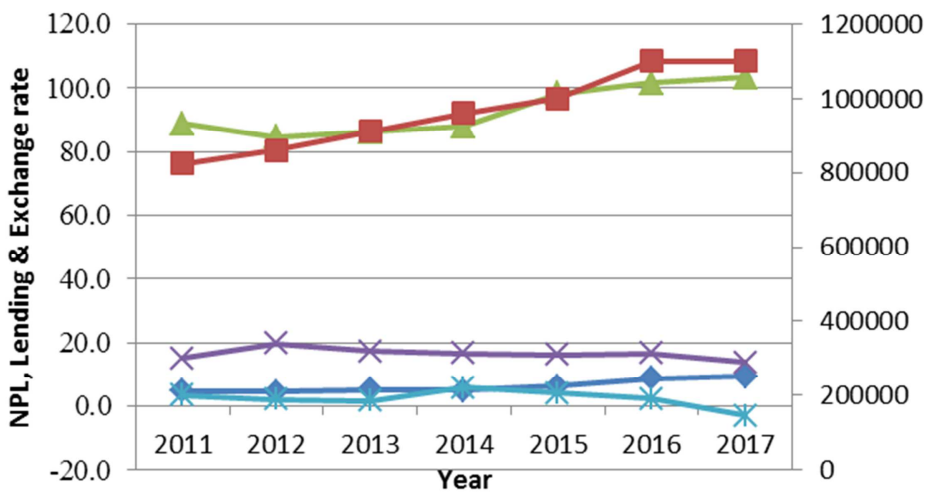

Figure 1. The trend of the macro-economic indicators of non-performing agricultural loans (Billions, KES); GDP (Billion, KES), Exchange rate and Lending rate.

Table 1. The macro-economic factors influencing credit in Kenya.

\begin{tabular}{llll}
\hline Variables & Minimum & Maximum & Mean \\
\hline Total agricultural non-performing loans (Billions of KES) & 4.00 & 10.14 & 6.14 \\
Real GDP (Millions of KES) & 807482 & 1147736 & 967906 \\
Real GDP growth (\%) & 3.50 & 7.50 & 5.48 \\
Real effective exchange rate & 82.24 & 103.52 & 106496 \\
Gross agricultural loans (Millions of KES) & 45.13 & 100.09 & 9.95 \\
Growth in loan portfolio & -8.65 & 13.61 & 72.70 \\
Lending rate & 13.65 & 20.21 & 2.24 \\
\hline
\end{tabular}

KES, Kenya Shillings; GDP, Gross Domestic Product; SD, standard deviation. accounts whose principal or interest remains unpaid 90 days or more after the due date. NPL level measurement (IMF, 2005; Banking Act, 2008) formula is as under:

$$
\text { NPL }(\%)=\frac{\text { Agricultural NPL }}{\text { Total Agricultural Loans Advanced }} \times 100
$$

\section{Results and Discussion}

\subsection{The Credit Sector Portfolio in Kenya}

Results show the summary statistics of the selected variable used in this study (Table 1). There was a general increase in all the values (the real GDP, gross agricultural loans, and real effective exchange rate) used in this study over time except for the loan portfolio and the lending rates. Total agricultural non-performing loans ranged from KES 410.14 Billion during the study period and the real effective exchange rate ranged between KES 82.24 per USD and KES103.52 per USD over the study period. The effect of the increase in the exchange rate manifest as a boost to economic growth where the lower exchange rate makes exports cheaper and increases the demand for domestic goods. The increase in demand for domestic goods could have led to an increase in the demand for loans for agriculture that ranged between KES 45.13 and 100.09 million. The lending rates were expected to be constant after Kenya enacted a law capping interest rates charged by commercial banks to be four units above the base lending rate by the central bank. During the study period, the lending rate ranged between 13.65 and 20.21 percent. 
Trend analysis (Figure 1) show a steady increase in GDP and NPL between 2011 and 2017. GDP recorded the highest value in 2016 and the non-performing loans had the highest value in 2017. The real effective exchange rate decreases between 2011 to 2014 then increased exponentially between 2014 and 2015 then a steady increase between 2015 and 2017 with a slight increase in the exchange rate. The lending rate increased between 2011 and 2012 then decreased steadily from 2012 to 2017. The growth in loan portfolio decreased between 2011 and 2013 then increased slightly in 2014 but dropped again from 2015 to 2017 with 2017 recording the lowest growth in the loan portfolio.

\subsection{Correlation Between Macro-economic Factors and NPL}

Table 2 below shows the correlation results for macroeconomic variables. The results indicate that the ratio of nonperforming agricultural loans of commercial banks had a strong positive correlation with real GDP $(0.841, \mathrm{p}<0.001)$. According to the study results (Table 2), there was a significant positive correlation between agricultural NPL and real effective exchange rate $(0.865, \mathrm{p}<0.001)$. Agricultural NPL had a weak inverse correlation with the average bank lending rate $(-0.48, p<0.01)$. The study results (Table 2$)$ also indicate that growth in loan portfolio does not have any correlation with non-performing agricultural loans.

Table 2. Correlation between key variables and the NPLs.

\begin{tabular}{lllll}
\hline Variables & Agricultural NPL & Real GDP & Real effective exchange rate & Average bank Lending Rate \\
\hline Real GDP & $0.841^{* * *}$ & 1.000 & & \\
Real effective exchange rate & $0.865^{* * *}$ & $0.812^{* * *}$ & 1.000 & 1.000 \\
Lending rate & $-0.480^{* *}$ & $-0.414^{*}$ & $-0.462^{*}$ & 0.0640 \\
Growth in loan portfolio & -0.241 & -0.237 & -0.138 & \\
\hline
\end{tabular}

GDP, Gross Domestic Product; ${ }^{*} p<0.05,{ }^{* *} p<0.01,{ }^{* * *} p<0.001$.

\subsection{Regression Analysis}

The causes of non-performing agricultural loans in commercial banks in Kenya were investigated using linear regressions with non-performing loans as the dependent variable and real GDP, real effective exchange rate, average bank lending rate and growth in the loan portfolio as independent variable. The results are presented in Table 3 below. The study established the economic model as follows:

$$
Y=-11.30+0.0000069 X_{1}+0.131 X_{2}-0.83 X_{3}-0.25 X_{4}
$$

According to the regression equation established, taking all variables constant at zero, the ratio of non-performing loans will decrease at 11.3 percent at 95 perent level of confidence. The coefficients in table 3 depict a positive relationship between agricultural NPL and real GDP $\left(\beta_{1}=0.0000069\right)$ and also a positive relationship between agricultural NPL and real effective exchange rate $\left(\beta_{2}=0.131\right)$. However, the relationship between the average bank lending rate and growth in agricultural loan is not significant.

Table 3. Regression coefficients.

\begin{tabular}{|c|c|c|c|c|c|c|c|}
\hline \multirow[t]{2}{*}{ Coefficients } & \multicolumn{2}{|c|}{$\begin{array}{l}\text { Unstandardized } \\
\text { Coefficients }\end{array}$} & \multirow{2}{*}{$\begin{array}{l}\text { Standardized } \\
\text { Coefficients } \\
\text { Beta } \\
\end{array}$} & \multirow[t]{2}{*}{$\mathbf{t}$} & \multirow[t]{2}{*}{ Sig. } & \multicolumn{2}{|c|}{$\begin{array}{l}\text { 95.0percent Confidence Interval } \\
\text { for B }\end{array}$} \\
\hline & B & Std. Error & & & & Lower Bound & Upper Bound \\
\hline (Constant) & -11.3 & 3.471 & & -3.256 & 0.003 & -18.48 & -4.121 \\
\hline Real GDP, (KES Millions) & $6.91 \mathrm{E}-06$ & 0 & 0.369 & 2.336 & 0.029 & 0 & 0 \\
\hline $\begin{array}{l}\text { Real effective exchange rates (Average } \\
\text { exchange rate against USD) }\end{array}$ & 0.131 & 0.04 & 0.517 & 3.258 & 0.003 & 0.048 & 0.214 \\
\hline $\begin{array}{l}\text { Average Commercial Bank Lending } \\
\text { Rate }\end{array}$ & -0.083 & 0.1 & -0.084 & -0.831 & 0.415 & -0.289 & 0.123 \\
\hline
\end{tabular}

a. Dependent Variable: Total Agricultural non-performing loans (Kshs, Billions).

Source: Research data.

\subsubsection{Robustness of the Model}

This entailed testing the 'goodness of fit' of the model to the actual data and the extent to which the independent variables explained the variation in the dependent variables. Table 4 shows that the adjusted $\mathrm{R}^{2}$, which is the coefficient of determination measuring the proportion of variation in non- performing agricultural loans in commercial banks in Kenya is 0.783 indicating that about $78.3 \%$ of variation in the dependent variable in the regression model are due to independent variables while $21.7 \%$ is due to other factors not captured in the model. 
Table 4. Statistics describing the robustness of the model.

\begin{tabular}{|c|c|c|c|c|c|c|c|c|c|}
\hline \multicolumn{10}{|c|}{ Model Summary } \\
\hline \multirow{2}{*}{ Model } & \multirow{2}{*}{$\mathbf{R}$} & \multirow{2}{*}{$\begin{array}{l}\mathbf{R} \\
\text { Square }\end{array}$} & \multirow{2}{*}{$\begin{array}{l}\text { Adjusted R } \\
\text { Square }\end{array}$} & \multirow{2}{*}{$\begin{array}{l}\text { Std. Error of the } \\
\text { Estimate }\end{array}$} & \multicolumn{5}{|l|}{ Change Statistics } \\
\hline & & & & & R Square Change & F Change & df1 & df2 & Sig. F Change \\
\hline 1 & $.903^{\mathrm{a}}$ & .815 & .783 & 929568402318200 & .815 & 25.393 & 4 & 23 & .000 \\
\hline
\end{tabular}

a. Predictors: (Constant), Average Commercial Bank Lending Rate, Growth in loan portfolio, Real GDP, (KES Millions), Real effective exchange rates (Average exchange rate against USD).

\subsubsection{Analysis of Variance (ANOVA) of the Regression Model}

Table 5 shows that the F-statistics is 25.393 and is significant at $\mathrm{P}<0.0001$. Thus, the independent variables in the model jointly influence non-performing agricultural loans in commercial banks in Kenya. The model was therefore considered robust or fitted well to the actual data of the variable.

Table 5. ANOVA model.

\begin{tabular}{lllllll}
\hline ANOVA & & & & & \\
\hline Model & & Sum of Squares & Df & Mean Square & F & Sig. \\
\hline \multirow{4}{*}{1} & Regression & 87.768 & 4 & 21.942 & 25.393 & $.000^{\text {b }}$ \\
& Residual & 19.874 & 23 & .864 & & \\
& Total & 107.642 & 27 & & & \\
\hline
\end{tabular}

a. Dependent Variable: Total Agricultural non-performing loans (Kshs, Billions).

b. Predictors: (Constant), Average Commercial Bank Lending Rate, Growth in loan portfolio, Real GDP, (KES Millions), Real effective exchange rates (Average exchange rate against USD)

There is a positive relationship between the ratio of non-performing loans and real GDP of $\left(\beta_{1}=0.0000069\right)$. This means a 1 percent increase in real GDP results in an increase in non-performing agricultural loans by KES 690 thousand. The positive relationship between NPL and real GDP contradicts results by $[15,7,12]$ who found that as GDP increase the NPL decreased. It is often expected that as real GDP increases, the real incomes of all economic agents also increase leading to an increase in their repayment capacity. There is a positive and significant association between real effective exchange rate and nonperforming loans $(\beta 2=0.131)$. In the model, an increase in the effective exchange rate by KES 1 results in an increase in non-performing agricultural loans by KES 0.131 Billion. There is a negative but non-significant association between the lending rate and non-performing loans $(\beta 3=-$ 0.083 ). The lending rate is a direct cost to loanees who service the loan from the proceeds of investments achieved using the loans. Higher lending rates will mean a higher repayment amount.

\section{Conclusion and Recommendations}

This study attempted to ascertain the effect of four selected factors (real Gross Domestic Product, real effective exchange rate, average commercial lending rate, and growth in agricultural loans on agricultural non-performing agricultural loans in the Kenya banking sector using multiple linear regression analysis. The study has shown that real effective exchange rate and growth in real Gross Domestic Product have a significant positive effect on the level of non-performing loans in the agricultural sector whereas the effect of average bank lending rate and growth in the loan portfolio was not significant. The results of the present study are consistent with international evidence which has shown that the real effective exchange rate has a significant positive impact on non-performing loans [10]. The study also found evidence of a significant positive relationship between real GDP and non-performing agricultural loans. This means that strong performance in the real economy may result in higher non-performing agricultural loans because loans are issued to probably few borrowers which affect the ability of the commercial banks to diversify their portfolio. This is coupled with the fact that the sector is quite fragmented with many small borrowers who are normally affected by the micro and macroeconomic environment. Risk of default, therefore, increases in absolute terms. The study, therefore, concluded based on the results that commercial banks should pay close attention to the two factors (real Gross Domestic Product and Real Effective Exchange rate) when providing loans to the agricultural sector to reduce the level of impaired loans. The banks active in agricultural lending should, therefore, take the performance of the real economy into account when extending loans given the reality that loan delinquencies are likely to be higher during periods of economic boom as suggested by the study results. Equally Commercial banks should trade with high prudence to curb a possible impairment due to reckless lending and overestimation of the borrower's ability to pay back. They should constantly review the complexity and diversity of the new loans to the agricultural sector periodically like quarterly, and do aging analysis to ensure that the growth in agricultural loans do not serve to window dress the portfolio at risk percentage while the actual amounts in default are increasing. 


\section{References}

[1] Ascui, F. \& Cojoianu, T. (2019). Natural Capital Credit Risk Assessment in Agricultural Lending: An Approach Based on the Natural Capital Protocol. Oxford: Natural Capital Finance Alliance.

[2] Ayanda, I. \& Ogunsekan, O. (2012). Farmers' Perception of Repayment of Loans Obtained from Bank of Agriculture, Ogun State, Nigeria. Journal of Agricultural Sciences, 3, 21-27.

[3] BE. \& Smith, M. (1998). Loan Delinquency in Community LendingOrganisations:Case Studies of NeighborWorks Organizations. Housing Policy Debate, 9 (14), 8-10. doi:http://dx.doi.org/10.1080/10511482.1998.9521289.

[4] Bofondi, M. \& Ropele, T. (2011). Macroeconomic determinants of bad loans: evidence from Italian banks. Bank of Italy Occasional Paper.

[5] CBK. (2015). Bank Supervision Report. Nairobi: Central Bank of Kenya. Retrieved from https://www.centralbank.go.ke/uploads/399346751_2015\%20 Annual\%20Report.pdf.

[6] CBK. (2016). Bank Supervision ANnual Report. Nairobi: Central Bank of Kenya. Retrieved from https://www.centralbank.go.ke/2017/08/25/2016-banksupervision-annual-report/.

[7] Fofack, H. L. (2005). Nonperforming loans in Sub-Saharan Africa: causal analysis and macroeconomic implications, The World Bank.

[8] Foos, D., Norden, L., \& Weber, M. (2009). Loan growth and riskiness of banks. Centre for Economic Policy Research (CEPR), (pp. 25-27). London, United Kingdom: University of Mannheim, Germany. Retrieved from Electronic copy available at: http://ssrn.com/abstract $=1045001$.
[9] Kamau, C. G. \& Mohamed, H. B. (2018). Efficacy of Monitoring and Evaluation Function in Achieving Project Success in Kenya: A Survey of County Government's Projects. IJAME.

[10] Khemraj, T. \& Pasha, S. (2009a). The determinants of nonperforming loans: an econometric case study of Guyana.

[11] Mogaka, A. J., Kiweu, J. M. \& Kamau, R. G. (2015). The influence of macro-economic factors on mortgage market growth in Kenya.

[12] Mwega, F. M. (2016). Financial regulation in Kenya: Balancing inclusive growth with financial stability. Achieving Financial Stability and Growth in Africa. Routledge.

[13] Onguka, D., Iraya, C. M., Kaijage, E. S.\& Kisaka, S. E. (2018). Impact of Corporate Control on Corporate Value: Evidence from Nairobi Securities Exchange.

[14] Safavian, M. \& Zia, B. 2018. The impact of interest rate caps on the financial sector: evidence from commercial banks in Kenya, The World Bank.

[15] Salas, v. \& saurina, J. (2002). Credit risk in two institutional regimes: Spanish commercial and savings banks. Journal of Financial Services Research, 22, 203-224.

[16] Sharma, U. \& An, Y. 2018. Accounting and Accountability in Fiji: A review and synthesis. Australian Accounting Review, 28, 421-427.

[17] Von Pischke, J. D. \& Adams, D. W. (1980). Fungibility and the design and evaluation of agricultural credit projects. American Journal of Agricultural Economics, 62, 719-726.

[18] World Bank. (2016). Agriculture and achieving the millenium development goals. REPORT NO. 32729-GLB, pp. 3-18. Retrieved from http://reliefweb.int/sites/reliefweb.int/files/resources/F7FC8E4 FA7224D3DC125717100507EE1-ifpri-gen-may06.pdf. 